\title{
The evolution of reproductive rights in view of bioeconomics
}

\author{
Georgy Romanovsky, ${ }^{1, *}$ Olga Romanovskaya ${ }^{2}$, and Darya Artyomova $^{3}$ \\ ${ }^{1}$ Department of Criminal Law, Institute of Law, Penza State University, 440026 Penza, Russian Federation \\ ${ }^{2}$ Department of Legal Disciplines, Institute of Law, Penza State University, 440026 Penza, Russian Federation \\ ${ }^{3}$ Department of Justice, Institute of Law, Penza State University, 440026 Penza, Russian Federation
}

\begin{abstract}
The article considers a general concept of reproductive rights, its primary enshrinement into international documents, and manifestation in specific laws adopted in post-Soviet space (including the Russian Federation). Various approaches to legal regulation based on direct enshrinement of specific reproductive rights, and determination of a legal regime of assisted reproductive technologies are shown. Some examples taken from legislation of the Republic of Armenia, the Republic of Belarus, the Republic of Kazakhstan, and the Kyrgyz Republic are given. The Western European experience based on the regulation of technologies rather than on provision of new basic human rights is presented. Effects of inclusion of reproductive technologies into economically evaluated medical industry are analyzed. It is highlighted that regulatory logic of reproductive technologies in Russia is largely based on market approaches, and any medical intervention is considered to be a civil service. Meanwhile, according to 2020 Constitutional amendments, Article 114 of the Constitution of the Russian Federation enshrined preservation of traditional values. Thus, a theological approach to the regulation of most biomedical issues seems to be relevant.
\end{abstract}

\section{Introduction}

Currently, novel reproductive technologies have become widespread worldwide. A legal effect of their evolution was both new legal regimes and specific rights were called reproductive rights (Latin: re, again + productio, production), that is, those related to reproduction of population.

Reproductive rights were first incorporated into such international non-binding documents as the Programme of Action adopted at 1994 International Conference on Population and Development in Cairo, and the Platform for Action adopted at 1995 Conference on Women in Beijing. We note that the Holy See and the Russian Orthodox Church showed little enthusiasm towards innovations. There were extreme viewpoints specifying the "Cairo yoke" domination in some publications of representatives of the Russian Orthodox Church.

Similar theses are being circulated by many politicians both in Russia and abroad. In particular, the issue of the right to abortion is highly politicized. In the United States, its solution depends on whether Democrats or Republicans are in power. Donald Trump, being the President of the United States, promptly reinstated the restrictions on funding organizations defending the unconditional right of women to abortion, which had been previously imposed by George W. Bush in 2001, and canceled by Barack Obama in 2009 [1]. Such a seesaw policy is subject to harsh criticism, which forces supporters of abortion to be engaged in a detailed search for moral compass in enshrinement of appropriate reproductive right [2], or insist on discrimination [3], which is most common when defending rights in the judiciary.

Reproductive rights relate to population reproduction, being a variously interpreted complicated problem. On the one hand, a balanced view on population growth has been often emphasized at the international level. On the other hand, demography is a national project for individual countries, Russia being the one. The People's Republic of China can serve an example of a diverse approach to demography. For a long time, the country had been guided by the principle of the one-child policy resulted in a disproportion across generations.

This approach has been revised nowadays. Thus, most issues related to the regulation of demographic processes are politicized. Their solution depends on numerous factors, and political necessity outweighing personal interests of citizens. Apparently, the lack of consensus on this issue determines the refusal to develop universal documents, and to form a new generation of human rights.

\section{Reproductive rights in the countries of Commonwealth of Independent States and Western Europe}

Constitution acts do not facilitate the process of enshrining reproductive rights, as the latter are found neither in the Constitution of the Russian Federation, nor in constitutions of the Commonwealth of Independent States (CIS), nor in recently adopted constitutions of

* Corresponding author: vlad93@sura.ru 
Eastern Europe countries. Currently, the concept of reproductive rights is not accepted, and there are no initiatives on its inclusion into basic laws.

In the post-Soviet space, such specific laws as the Law of the Republic of Armenia No. ZR-474 of 26 December 2002 on Reproductive Health and Rights to Reproduction and the Law of the Kyrgyz Republic No. 148 of 4 July 2015 on Reproductive Rights of Citizens and Guarantees of their Realization were adopted. There were major problems in conceptualization of certain reproductive rights, since delicate reproductive sphere affects human intimacy aspects, which cannot be formalized according to the rules of the legal procedure. Article 9 of the Law of the Kyrgyz Republic is devoted to the right to freely decide on the number of children born both within and outside of marriage. This formally enshrines the right to adultery, which is unlikely to be recognized by national legal systems. Besides, Article 9 Part 2 provides for a guarantee of non-interference in this right enforcement, and Part 3 supplements the requirement to maintain information confidentiality related to the enforcement of human sexual and reproductive rights. Such rules (based on textual interpretation) prohibit any family disputes without any exceptions. Meanwhile, when resolving a dispute (e.g., on paternity), confidentiality will be definitely violated in judiciary. Besides, interpersonal relationships, especially in case of revealed marital infidelity, are unlikely to be based on maintaining confidentiality (at least, within the family). In fact, such declarative formulations only create an illusion of legal regulation.

In the CIS countries, the main object of regulation is reproductive technologies, rather than protected specific human rights (e.g., the Law of the Republic of Uzbekistan No. ZRU-528 of 11 March 2019 on Protection of Reproductive Health of Citizens; the Law of the Republic of Belarus No. 341-Z of 7 January 2012 on Assisted Reproductive Technologies). The Code of the Republic of Kazakhstan No. 193-IV ZRK of 18 September 2009 on Public Health and Health Care System, being in force until 2020, enshrined the system of reproductive rights in Chapter 17. A new Code No. 360-VI of 7 July 2020 on Public Health and Health Care System refers to assisted reproductive methods and technologies in Chapter 18, devoted to regulation of individual relations in the field of healthcare.

In Western European countries, the attitude towards reproductive rights is very cautious. It does not exclude special regulation of reproductive technologies (e.g., the German Embryo Protection Act of 1990 (to determine aspects of reproductive activity, and issues of cloning, preimplantation genetic diagnosis, creation of embryological chimeras, etc.). In the UK there is the Human Fertilization And Embryology Act of 1990; the French Law No. 2004-800 of 6 August 2004 on Bioethics). In most cases, they analyze obligations of the state to ensure reproductive health, such as induced abortion [4], services of medical organizations on family planning [5], prevention of teenage pregnancy in educational institutions [6], and other issues related to the organization of specialized medical care. This approach is most convenient because it allows the state to quickly vary policy, while maintaining basic human rights that have received general recognition [7].

At the European level, the Convention for the Protection of Human Rights and Dignity of the Human Being with regard to the Application of Biology and Medicine has been adopted: the Convention on Human Rights and Biomedicine (Oviedo, 1997; hereinafter - the Oviedo Convention). Four Additional Protocols have been adopted to this document:

- Protocol on the Prohibition of Cloning Human Beings;

- Protocol on Transplantation of Human Organs and Tissues;

- Protocol on Biomedical Research;

- Protocol on Genetic Testing for Health Purposes.

Certain provisions of the Convention are devoted to reproductive rights. At the same time, there is a general approach to regulating special issues. Much attention is paid to the discretion of the state. The European Court of Human Rights, in its decisions on reproductive rights, also avoids contentious issues. The motive for such decisions is to state the lack of consensus among European countries.

There is no specific law on reproductive rights in the Russian Federation. There were only attempts to adopt such an act in the constituent entities of the Russian Federation (in particular, in the Ivanovo region), but in most cases parliamentarians made a decision either to reject or subsequently repeal thereof. Article 55 of the Federal Law No. 323-FZ of 21 November 212011 on Basics of Health Protection of the Citizens in the Russian Federation is devoted to assisted reproductive technologies at the federal level. The law defines the legal, economic and organizational basis for the protection of the health of citizens, their rights and responsibilities in this area, and ensures their implementation. The law also establishes the powers and responsibilities of the authorities, rights and duties of medical organizations, pharmaceutical and health care workers.

The procedure for using assisted reproductive technologies, contraindications and restrictions on their use was approved by the Order of the Ministry of Health of the Russian Federation No. 803n of 31 July 2020. Regulation transfer to the sub-legislative level enables changing parameters of any technology as quickly as possible with public request for such adjustments. Reproductive rights are a very sensitive area (in all respects). Formulating strong commitments and mandatory rules can have unpredictable consequences. This or that sense of individual rules can differ from various factors: political, economic, religious.

Article 55 of the Federal Law on Basics of Health Protection of the Citizens in the Russian Federation contains the following information:

- the concept of assisted reproductive technologies is fixed;

- it is allowed to resort to assisted reproductive technologies for both men and women;

- the use of assisted reproductive technologies by a single woman is allowed; 
- there is no ban on access to assisted reproductive technologies for homosexual couples;

- citizens have the right to cryopreservation and storage of their sex cells, tissues of reproductive organs and embryos

- surrogacy services are provided on the basis of a contract.

The Federal Law on Basics of Health Protection of the Citizens in the Russian Federation provides the following. A surrogate mother can be a woman between the ages of twenty and thirty-five, who has at least one healthy child of her own, who has received a medical certificate of satisfactory health status, and who has given written informed voluntary consent to medical intervention. A woman in a marriage registered in accordance with the procedure established by the legislation of the Russian Federation can be a surrogate mother only with the written consent of her spouse. A surrogate mother cannot be an egg donor at the same time.

The regulatory logic of reproductive technologies in Russia is largely based on market approaches, and any medical intervention is considered to be a civil service.

Some reproductive technologies have become the subject of assessment in the Constitutional Court of Russia. The following solutions should be mentioned:

- Decision of the Constitutional Court of the Russian Federation of July 19, 2016 No. 1494-O and Decision of the Constitutional Court of the Russian Federation of January 26, 2017 No. 114-O. Complaints were directed at the prohibition of government funding for artificial termination of pregnancy. The Constitutional Court of Russia recognized such funding as admissible;

- Decision of the Constitutional Court of the Russian Federation dated September 27, 2018 No. 2318-O. The applicants demanded the expansion of the rights of the parents who paid for the services of surrogate mothers. The Constitutional Court of Russia refused to satisfy the claims.

\section{Reproductive technologies and bioeconomics}

There is another regulation aspect of reproductive technologies, namely, their inclusion into economically evaluated medical industry. Firstly, medical care for in vitro fertilization (IVF) has been approved by the Decree of the Government of the Russian Federation No. 2299 of 28 December 2020 on the Program of State Guarantees for the Provision of Free Medical Care to Citizens for 2021 and for Planned Period of 2022 and 2023. In 2019, over 9.5 billion rubles were planned for the provision of this type of assistance. Actually, more than 9.8 billion rubles were spent to pay for 79,566 cycles. It should be understood that the declared guarantees cover only part of the costs necessary for a full IVF cycle. In practice, a little more than 100,000 rubles compensated by the state is only half (and in some cases, a quarter) of the real cost of an IVF cycle, considering the cost of drugs.
Secondly, various reproductive technologies widespread in Russia have a significant cost estimate. In particular, due to banned commercial surrogacy in India and Thailand in 2016, a demand shifted to other countries, and Russia providing relevant services. Caused by liberal approach to the regulation of this program, many foreign clients turned to Russian clinics. Unfortunately, there are no statistical data on children born from surrogacy in Russia. Provided customers being foreign couples, it is difficult to track the purpose of a child birth, since such information is not reflected in each corresponding database. Independent mass media estimate the annual number of newborns under this program to be 20,000 births. There was an annual increase of about $20 \%$ for several years (before the pandemic).

In June 2021, a group of deputies of the State Duma of the Russian Federation (including Deputy Chairman of the State Duma P. Tolstoy) officially registered the draft Federal Law. It provides for amendments to the Family Code of Russia, Federal Law on Basics of Health Protection of the Citizens in the Russian Federation, and the Federal Law on Acts of Civil Status. The adoption of the project will mean a ban on surrogacy for foreign citizens on the territory of the Russian Federation. It is still difficult to determine his fate. The country's parliament has a strong lobby for a different approach to surrogacy.

The legal press has repeatedly voiced the demands to impose severe restrictions on a number of assisted reproductive technologies (at least following the example of most European countries), but only the scandal with the children in 2020 revived the forgotten discussion. Back in September 2009, A. Baranov, Russian chief pediatrician, vice president of RAMS, spoke very carefully about the importance of assisted reproductive technologies, confirming his statement with the data: $2 / 3$ of children born as a result of extracorporal fertilization suffer from serious diseases, and the women who turn to this procedure cause damage to their health. But then his professional opinion caused an avalanche of criticism.

This program is the most expensive one. According to the Accounts Chamber of the Russian Federation, the number of organizations providing such services has increased by $10 \%$ from 2018 to 2020 (as stated in the Report on the results of analysis of the efficiency of compulsory health insurance expenditure in 2019 and the expired period of 2020 during in vitro fertilization procedure). Over $80 \%$ of organizations are privately owned, which obliges them to participate in the competition. Besides, the demand for such services will increase due to numerous infertile couples (from 17 to $24 \%$ in Russia, depending on the region).

Thirdly, the very regulation logic of reproductive technologies in Russia is largely based on market approaches. Chapter 39 of the Civil Code of the Russian Federation classifies the provision of medical care as a type of services covered by the legislation of consumer protection. Article 55 of the Federal Law on Basics of Health Protection of the Citizens in the Russian Federation provides for the conclusion of an agreement 
when implementing a surrogate motherhood program. These approaches do not find general support either among the medical community or among lawyers [8]. In particular, a surrogacy agreement is not recognized as a type of civil contract by many scientists [9]. Some authors note that even it is provided by the current legal order, it is necessary to take into account ethical principles that may prevail when resolving arisen legal disputes [10]. V. V. Momotov, Chairman of Judicial Council of the Russian Federation, Judge of the Supreme Court of the Russian Federation, believes that the model of paid service contract is fully applicable to surrogate motherhood agreement [11]. This opinion correlates with provisions of the Constitutional Court of the Russian Federation in Determination No. 880-O of 15 May 2012 and Determination No. 2318-O of 27 September 2018, and of the Supreme Court of the Russian Federation presented in Paragraph 31 of the Resolution of the Plenum of the Supreme Court of the Russian Federation No. 16 of 16 May 2017 on the Application by Courts of Law in the Consideration of Causes Related to the Identification of the Child's Origin. It should be noted that disputes on relationships between program participants, on the subject of the agreement, and the nature of the obligations imposed on the participants in the process of giving birth to a child are still urgent, although they arose almost immediately after successful experiments [12, 13].

The inclusion of reproductive technologies into the system of economic categories has diverse effects. Negative aspects concern intimate relationships being turned into an element of industrial production. It leads to life devaluation and axiological change with humancentered philosophy, and ethics and morality lined up in the general scale of anthropocentrism.

There are numerous proponents of posthumanism worldwide nowadays, focusing on an illusory privilege of Homo sapiens. Utilitarian-based political and legal doctrines are being initiated. In particular, the netocracy concept by A. Bard and J. Söderqvist [14] is upheld in Russia in attempting to create a related political party.

\section{Law and ethics of reproductive technologies}

The conception of biolaw is a response to the formation of an economic approach to regulate reproductive technologies, which determines ethical assessment priority thereof. Being its element, bioethics has a significant number of proponents both in Russia and abroad. Therein it should be considered that axiological requirements are created at the stage of shaping a scientific idea, preceding the development of a technology, subject to assessment. These requirements are most typical for such human-related research areas as biomedicine, human-computer interaction, artificial intelligence, etc. The paradigm shift has led to the emergence of a new term called value sensitive design (VSD), being a general ethical approach to engineering and technological innovations $[15,16]$.
Basic issues in modern reproductive medicine are represented in the Fundamentals of the Social Concept of the Russian Orthodox Church, approved by the Bishops' Council in Moscow (13-16 August 2000). Having occupied an important place in the general ethics of Russian society, preservation of traditional values is enshrined in Article 114 of the Constitution of the Russian Federation in accordance with the Law on amendment to the Constitution of the Russian Federation No. 1-FKZ of 14 March 2020 on Improving the Regulation of Certain Aspects of the Organization and Functioning of Public Authority. Thus, Christian values guide the development of legislation. A theological approach to key issues in reproductive medicine, facilitating its acceptance by major legal institutions, is being developed in social sciences.

Currently, the Church-Public Council for Biomedical Ethics of the Russian Orthodox Church adopts various documents on modern biomedicine issues. The Council is not engaged in law-making activity, and the Statement on the Inviolability of Human Life from the Moment of Conception being its only adopted document (June 2019).

\section{Conclusions}

Based on the given arguments, in the Russian Federation it is necessary:

- to define a common concept of legal support for the development of reproductive medicine;

- to reveal development patterns of related legal institutions in view of foreign experience and the acceptance of international legal acts by the Russian national legal system;

- to establish regulation principles of reproductive technologies;

- to develop a theological approach to urgent problems in reproductive medicine;

- to specify forms of relationship between law and Christian ethics in regulating reproductive technologies.

\section{References}

1. G. Cleaver, The Lancet, 389, 2361-2362 (2017)

2. W.J. Parker, Best Pract. Res. Clin. Obstet. Gynaecol., 62, 3-10 (2020)

3. J.N. Erdman, R.J. Cook, Best Pract. Res. Clin. Obstet. Gynaecol., 62, 11-24 (2020)

4. B.J. Hill, Columbia Journal of Gender and Law, 18, 1-49 (2009)

5. C. Davey, Reproductive Health Matters, 13, 25 (2005)

6. A. Hadley, R. Ingham, V. Chandra-Mouli, Reprod. Health, 13, 139 (2016)

7. G.B. Romanovskii, Perm University Herald. Juridical Sciences, 37, 260-271 (2017)

8. S. Morozova, Kutafin University Law Review, 1, 198-203 (2016) 
9. D.A. Belova, Laws of Russia: Experience, Analysis, Practice, 11, 88-94 (2020)

10. J.C. Callahan, J. Clin. Ethics. Spring, 4, 82-91 (1993)

11. V.V. Momotov, Lex Russica, 1, 29-39 (2019)

12. Sh. O'Brien, North Carolina Law Review, 65, 127153 (1986)

13. B. Cohen, T.L. Friend, Clin. Perinatol., 14, 281-329 (1987)
14. A. Bard, J. Sšderqvist, The Netocracts: Futurica Trilogy (Stockholm Text, 2012)

15. S. Kheirandishab, M. Funka, S. Wensveena, M. Verkerkc, M. Rauterberga, Technol. Soc., 62, 112 (2020)

16. J. Van den Hoven, G.J. Lokhorst, I. Van de Poel, Sci. Eng. Ethics, 18, 143-155 (2012) 